\title{
Extraction and Isolation of Compound from Roots of Kniphofia pumila, and Its Antibacterial Activities in Combination with Zinc Chloride
}

\author{
Dele ABDISSA $^{1, *}$, Gezahegn FAYE ${ }^{2}$, Melkamu FAYERA ${ }^{1}$ and Shiferaw DEMISSIE ${ }^{3}$ \\ ${ }^{I}$ Department of Chemistry, College of Natural Sciences, Jimma University, Jimma, Ethiopia \\ ${ }^{2}$ Department of Chemistry, College of Natural Sciences, Salale University, Fiche, Ethiopia \\ ${ }^{3}$ Department of Biology, College of Natural Sciences, Jimma University, Jimma, Ethiopia
}

('Corresponding author’s e-mail: deleabdissa@gmail.com)

Received: 30 October 2018, Revised: 1 July 2019, Accepted: 30 August 2019

\begin{abstract}
Kniphofia pumila has been traditionally used for the treatment of different diseases in Oromiya regional state, western part of Ethiopia. Thus, the main objective of this study was to extract bioactive natural products from the roots of $K$. pumila and perform in vitro antibacterial activity tests against selected pathogens. Extraction of compound from the roots of $K$. pumila was carried out by maceration method at room temperature and its antibacterial activity was done using agar disc diffusion method. The crude extracts alone and along with $\mathrm{ZnCl}_{2}$ were tested against pathogenic bacteria Escherichia coli (ATCC 25722), Klebsiella pneumoniae subsp. pneumoniae (DSM 19613), Staphylococcus aureus (ATCC 25925) and Salmonella Typhimurium (ATCC 13311). Following its promising activity, the acetone crude extract that have shown better antibacterial activity was subjected to column chromatography for isolation of pure compound. Hence, one pure compound (GZ-1) was obtained from acetone crude extract. Meanwhile, the antibacterial activities of the isolated compound alone and in combination with $\mathrm{ZnCl}_{2}$ were also performed against all aforementioned bacterial strains. Then, isolated compound was characterized by using NMR spectroscopic techniques such as ${ }^{1} \mathrm{H}-\mathrm{NMR},{ }^{13} \mathrm{C}-\mathrm{NMR}$ and, $2 \mathrm{D}$ NMR, so as to establish its structure as 3'-acetyl-2',6'-dihydroxy-4-methoxyphenyl-1,8-dihydroxy-3methylanthraquinone, trivial name knipholone. Finally, GZ-1 was isolated from the roots of K. pumila and it was noted that the antibacterial activities of $\mathrm{ZnCl}_{2}$ in combination with crude extract as well as with isolated compound against E. coli (ATCC 25722), S. aureus (ATCC 25925) and S. Typhimurium (ATCC 13311) bacterial strains showed remarkable results which were greater than the antibacterial activity of the positive standard drug (gentamycin). To sum up, from the chromatographic isolation of roots acetone extract of $K$. pumila one pure compound (knipholone) was obtained. Its antibacterial activity was also evaluated in combination with $\mathrm{ZnCl}_{2}$ salt and alone.
\end{abstract}

Keywords: Kniphofia pumila, Knipholone, Maceration method, Crude extracts, Zinc chloride

\section{Introduction}

Man has used plants to treat common infectious diseases, and some of the traditional medicines are still part of the habitual treatment of various diseases [1]. Scientific interest in medicinal plant has multiplied in recent times due to increased efficiency of new plant derived drugs and rising concerns about the side effects of modern medicine, and hence the need to look for new molecular structures as lead compounds from the plant kingdom $[1,2]$. 
http://wjst.wu.ac.th

Medicinal plant-based drugs have the added advantage of being simple, effective and offering a broad spectrum of activity with greater emphasis on preventive action [3]. Natural products and their derivatives represent more than $50 \%$ of all the drugs in clinical use in the world [4]. The extensive use of natural plants as primary health remedies due to their pharmacological properties is quite common. Natural products are preferred for biological screening based on ethno-medical use of plants, because many infectious diseases are known to have been treated with herbal remedies throughout the history of mankind [5].

Ethiopia has rich and diverse flora. Its flora is estimated to contain between 6,500 and 7,000 species of higher plants, of which about $12 \%$ are endemic [6]. Plants have been used as a source of medicine in Ethiopia from time immemorial to treat different ailments [7]. It is, therefore, not surprising that some of these plants have chemical compounds of therapeutic values that can be used in the treatment of many diseases. Nevertheless, most of these medicinal plants within Ethiopian flora have not been phytochemically investigated [8,9]. In line with this fact, the genus Kniphofia is a rich source of anthraquinones, flavonoids and alkaloids, which are well-known for their broad range of bioactivities, including anticancer and antimalarial activities. Although the genus Kniphofia has been well explored, but the phytochemistry of $K$. pumila has not previously been investigated exhaustively [10].

It has been also reported that the antibacterial activities of different medicinal plant part extracts along with metal slats showed enhanced activities [11-14] when compared with the activities of isolated extracts. Particularly, Prashanth et al. [11] indicated stronger antibacterial activity result of Argyreia elliptica extracts in combination with zinc (II) salts. The enhanced antibacterial activities of mixed metal ions and extracts have been mentioned due to lipophilicity [11], and synergetic effects [12].

In the present study, we carried out extraction, isolation, purification, and characterization on the roots part of $K$. pumila. Following this, one compound (knipholone) was isolated and characterized by nuclear magnetic resonance (NMR) spectroscopic technique. And finally, its antibacterial activities along with $\mathrm{ZnCl}_{2}$ salt were evaluated on four bacterial strains by using agar disc diffusion method.

\section{Materials and methods}

Analytical grade Sigma-Aldrich product solvents, such as petroleum ether, n-hexane, chloroform, acetone, methanol, and ethyl acetate, were used for sequential extraction and column elution. Zinc (II) chloride, $\mathrm{ZnCl}_{2}$ (Analytical grade Sigma-Aldrich) and standard antibiotic drug (gentamycin) were used. Mueller Hinton agar and saline solution were also used as a culture medium during antibacterial test. Rotary vapor, column chromatography, round bottom flask, electrical balance, volumetric flask, measuring cylinder, pestle and mortar, filter papers, weighing balances, water bath, Uv-tech-254 and 365 $\mathrm{nm}$ chamber were used. And 1D $\left({ }^{1} \mathrm{H}-\mathrm{NMR} 500 \mathrm{MHz},{ }^{13} \mathrm{C}-\mathrm{NMR}(150 \mathrm{MHz})\right.$, DEPT-135) and 2D (COSY, HSQC and HMBC) spectra were recorded on Bruker Avance NMR in deuterated solvent.

\section{Plant sample collection and preparation}

The fresh root part of Kniphofia pumila plant sample was collected from Oromiya regional state, western part of Ethiopia. The sample was chopped into smaller pieces and shade dried in laboratory at room temperature. Then, it was powdered to facilitate easy of solvent penetration.

\section{Extraction and isolation}

The shaded dried root $(1 \mathrm{~kg})$ of powdered plant sample was sequentially extracted with $(2 \times 2.5 \mathrm{~L}$ petroleum ether, chloroform, acetone, and methanol) using maceration method at room temperature for 24 $\mathrm{h}$. The crude extracts of each solvent were filtered first through a fresh cotton plug and then through fluted filter paper. Then, the filtrates were concentrated by evaporation under reduced pressure using a rota vapor at $50{ }^{\circ} \mathrm{C}$. The resulting crude extracts of each solvent were stored in desiccator below $4{ }^{\circ} \mathrm{C}$ until used for microbial assay and thin layer chromatography (TLC) analysis. After observing the results of preliminary antibacterial activity tests of the crude extracts, then the one that shows the better activity was subjected to column chromatography for isolation. The column chromatography was packed with deactivated (in oven at $100{ }^{\circ} \mathrm{C}$ for $1 \mathrm{~h}$ ) silica gel $60-120 \mathrm{~mm}$ mesh size to isolate compound. Glass 
http://wjst.wu.ac.th

column of $4 \mathrm{~cm}$ diameter with a $60 \mathrm{~cm}$ length was packed with the deactivated $100 \mathrm{~g}$ silica gel slurry using petroleum ether. The appropriate solvent system for isolation of compound was made after carrying out the TLC analysis of the crude extract in various combinations of solvents with increasing polarity. Then, the crude extract was redissolved in acetone, concentrated to dry and adsorbed to the packed silica gel.

The dry sample adsorbed to the silica gel was eluted with an increasing gradient of solvent system polarity starting from 100:0 to $0: 100$ ratio of $n$-hexane to ethyl acetate. The fractions were collected. Hence, it was concentrated under reduced pressure using a rotary evaporator. The identities of the fractions were examined by TLC. The spots developed were visualized under UV-tech light at 254 and $365 \mathrm{~nm}$. The fractions that showed the same TLC profile (using retardation factor, $\mathrm{R}_{\mathrm{f}}$ were combined and concentrated to dryness under reduced pressure using a rotary evaporator.

Among 78 fractions, 12 - 16 (50\% ethyl acetate in n-hexane) was merged together and allowed to dryness to give compound GZ-1, which was identified as 3'-acetyl-2', 6'-dihydroxy-4-methoxyphenyl-1, 8-dihydroxy-3-methylanthraquinone (24.7 mg).

\section{Standard inoculums preparation}

For this study, the standard inoculum for antibacterial susceptibility test was prepared based on the standard set protocol. This standard was prepared by mixing two solutions of a $0.5 \mathrm{~mL}$ aliquot of 0.048 mol L ${ }^{-1} \mathrm{BaCl}_{2}\left(1.175 \% \mathrm{w} / \mathrm{v} \mathrm{BaCl}_{2} .2 \mathrm{H}_{2} \mathrm{O}\right)$ was added to $99.5 \mathrm{~mL}$ of $0.18 \mathrm{~mol} / \mathrm{L} \mathrm{H}_{2} \mathrm{SO}_{4}(1 \% \mathrm{v} / \mathrm{v})$ with Constant stirring to maintain a suspension. Hence, $0.5 \mathrm{McFarland}$ standard concentration, equivalent to cell density corresponds to $1.5 \times 10^{8} \mathrm{CFU} \mathrm{mL}^{-1}$, is a mixture of $0.5 \mathrm{~mL}$ of $1 \%\left(\mathrm{BaCl}_{2} .2 \mathrm{H}_{2} \mathrm{O}\right)$ in $99.5 \mathrm{~mL}$ of $1 \% \mathrm{H}_{2} \mathrm{SO}_{4}$ solution. A small volume of turbid solution was transferred to a screw-cup bottle of the same types as used for preparing test and control inoculum. Culture containing test tube with approximately equal concentration or density with $0.5 \mathrm{McF}$ arland standards was used for inoculation of media.

Thus, freshly grown liquid culture of the test pathogens solution of having similar turbidity with 0.5 McFarland were seeded over the Muller-Hinton agar plates with a sterile swab. Sterile Whatman filter paper Discs $(6 \mathrm{~mm})$ were soaked with $30 \mu \mathrm{L}$ of the stock solution concentration of the extracts and air dried to evaporate the solvent and the discs were applied over the seeded plates at equidistance. All the bacterial strains were subcultured from the original culture, stored at $-70{ }^{\circ} \mathrm{C}$ and maintained on MullerHinton $(\mathrm{MH})$ agar plates at $4{ }^{\circ} \mathrm{C}$, and grown at $37^{\circ} \mathrm{C}$ when required.

\section{Antibacterial test using the agar diffusion method}

The following American Type Culture Collection (ATCC) standard strains were obtained from Jimma University, Microbiology Research Laboratory. The bioassay testes were done using E. coli (ATCC 25722), K. pnemonia (DSM 19613), S. aureus (ATCC 25925) and S. Typhimurium (ATCC 13311). Bacterial strains cultures were first grown on agar plates at $37{ }^{\circ} \mathrm{C}$ for $24 \mathrm{~h}$ prior to inoculation on to the nutrient agar. The $6 \mathrm{~mm}$ diameter sterile discs of what man № 3 paper was placed on the surface of the inoculated agar approximately at equal distance of corners in petri plates in a $200 \mathrm{mgmL}^{-1}$ concentration that were prepared by dissolving $200 \mathrm{mg}$ of crude extracts and isolated compound (GZ-1) in $1 \mathrm{~mL}$ of dimethyl sulfoxide (DMSO) using micro pipette on the discs. Similarly, $50 \mathrm{mgmL}^{-1}$ test solution of $\mathrm{ZnCl}_{2} \cdot 6 \mathrm{H}_{2} \mathrm{O}$ was also prepared. Whereas, the combined plant extracts and $\mathrm{ZnCl}_{2} \cdot 6 \mathrm{H}_{2} \mathrm{O}$, isolated compound and $\mathrm{ZnCl}_{2} \cdot 6 \mathrm{H}_{2} \mathrm{O}$ solutions were prepared by mixing their solutions in 1:1 ratio with stirring.

Then, test solution was added on the discs, allowed to diffuse for $5 \mathrm{~min}$. and the petri plates kept in an incubator at $37^{\circ} \mathrm{C}$ for $24 \mathrm{~h}$. The antibacterial activity resulted was recorded after $24 \mathrm{~h}$ by measuring the diameter of growth inhibition on the discs (in $\mathrm{mm}$ ) using transparent ruler in triplicates. Standard for anti-bacterial drug (Gentamycin) was used as positive control and DMSO as negative control. 


\section{Results and discussion}

\section{Characterization of isolated compound}

Compound GZ-1 which was isolated as a deep red amorphous solid had an $R f$ value of $0.8(50 \%$ ethyl acetate in n-hexane). Its molecular formula was anticipated as $\mathrm{C}_{24} \mathrm{H}_{18} \mathrm{O}_{8}$ on the basis of its $1 \mathrm{D}\left({ }^{1} \mathrm{H}\right.$ NMR $500 \mathrm{MHz},{ }^{13} \mathrm{C}-\mathrm{NMR}$ (150 MHz, DEPT-135) and 2D NMR (COSY, HSQC and HMBC) spectral data. In the ${ }^{1} \mathrm{H}$ NMR spectrum, two downfield shifted signals at $\delta_{\mathrm{H}} 12.60$ and 11.95 were observed due to chelated hydroxyl $(-\mathrm{OH})$ protons at $\mathrm{C}-1$ and $\mathrm{C}-8$ of an anthraquinones moiety. And the aromatic substituent in the compound displayed highly downfield shifted singlet $\left(\delta_{\mathrm{H}} 14.18\right)$ due to the chelated $\mathrm{OH}$ proton, an acetyl proton $\left(\delta_{\mathrm{H}} 2.73\right)$ at C-3', a sharp singlet at $\delta_{\mathrm{H}} 3.95$ due to a methoxy group showing that the substituent is acetylphloroglucinol methyl ether. Hence, the chrysophanol moiety with the aromatic protons of ring $\mathrm{C}(\mathrm{H}-5, \mathrm{H}-6$ and $\mathrm{H}-7)$ displaying an $\mathrm{ABX}$ spin system and resonating at $\delta_{\mathrm{H}} 7.58$ (dd, $J=6.0,6.1 \mathrm{~Hz}), 7.60(\mathrm{t}, J=6.2,6.1 \mathrm{~Hz})$ and $7.22(\mathrm{dd}, J=2.88,2.90 \mathrm{~Hz})$, respectively. Although meta coupled protons were expected for ring A, only a singlet was observed at $\delta_{\mathrm{H}} 7.30$ and was assigned to $\mathrm{H}-2$ with the methyl group $\left(\delta_{\mathrm{H}} 2.16\right)$ at C-3. This suggests that $\mathrm{C}-4\left(\delta_{\mathrm{C}} 132.4\right)$ is the point of connection with aromatic substituent whose presence was evident from the NMR spectrum.

The ${ }^{13} \mathrm{C}$ NMR spectrum (Table 1) displayed signals for 24 carbons, stands for five methine, sixteen quaternary carbon and eight oxygenated carbon including the three-carbonyl carbon. In this regard, the position of the carbonyl carbon at $\delta_{\mathrm{C}} 192.9$ (C-9) and $\delta_{\mathrm{C}} 182.9$ (C-10) and 203.7 (C-3') and hydroxyl ($\mathrm{OH})$ groups were established at $\delta_{\mathrm{C}} 163.4(\mathrm{C}-1)$ and $\delta_{\mathrm{C}} 162.0(\mathrm{C}-8)$ in the peri-position, grounded on the HMQC and HMBC analysis (Table 2). Therefore, compound GZ-1 was identified as 3'-acetyl-2',6'dihydroxy-4-methoxyphenyl-1,8-dihydroxy-3-methylanthraquinone, trivial name knipholone. It is widely distributed in the genus Kniphofia, Bulbine and Bulbinella.

Table $1{ }^{1} \mathrm{H}$ NMR $(500 \mathrm{MHz}),{ }^{13} \mathrm{C}$ NMR $(150 \mathrm{MHz})$ and Multiplicity for GZ-1 in $\mathrm{CDCl}_{3}$.

\begin{tabular}{|c|c|c|c|}
\hline C No & $\delta_{\mathrm{H}}(m, J$ in $\mathrm{Hz})$ & $\delta \delta_{\mathrm{C}}$ of $\mathrm{GZ}-1$ & Description \\
\hline 1 & - & 163.4 & - \\
\hline $1 \mathrm{a}$ & - & 115.5 & $\mathrm{QC}$ \\
\hline 2 & $7.30(s)$ & 120.2 & $\mathrm{Ar}-\mathrm{H}$ \\
\hline 3 & - & 152.6 & $\mathrm{QC}$ \\
\hline 4 & - & 133.0 & QC \\
\hline $4 a$ & - & 134.5 & QC \\
\hline 5 & $7.58(d d, 6.0,6.1)$ & 125.1 & Ar-H \\
\hline $5 a$ & - & 125.9 & QC \\
\hline 6 & $7.60(t, 6.2,6.1)$ & 137.3 & Ar-H \\
\hline 7 & $7.22(d d, 2.88,2.90)$ & 115.6 & Ar-H \\
\hline 8 & - & 162.0 & - \\
\hline $8 \mathrm{a}$ & - & 115.5 & QC \\
\hline 9 & - & 192.9 & QC \\
\hline 10 & - & 182.9 & $\mathrm{QC}$ \\
\hline 1 ' & - & 107.3 & QC \\
\hline $2^{\prime}$ & - & 162.0 & $\mathrm{QC}$ \\
\hline $3^{\prime}$ & - & 106.3 & QC \\
\hline $4^{\prime}$ & - & 163.0 & QC \\
\hline 5 & $6.15(s)$ & 90.0 & Ar-H \\
\hline
\end{tabular}




\begin{tabular}{cccc}
\hline C No & $\boldsymbol{\delta}_{\mathbf{H}}(\boldsymbol{m}, \boldsymbol{J}$ in Hz) & $\boldsymbol{\delta} \boldsymbol{\delta}_{\mathbf{C}}$ of $\mathbf{~ G Z - 1}$ & Description \\
\hline 6 ' & $(s)$ & 159.4 & $\mathrm{QC}$ \\
$\mathrm{Me}-3$ & $2.16(s)$ & 21.6 & $-\mathrm{CH}_{3}$ \\
$\mathrm{OCH}_{3}-4$ ' & $3.95(s)$ & 55.7 & $-\mathrm{OCH}_{3}$ \\
$\mathrm{COCH}_{3}-3$ ' & $2.66(s)$ & 33.3 & $-\mathrm{OCH}_{3}$ \\
$\mathrm{OH}-1$ & $12.60 / 11.95(s)$ & - & Chelated $\mathrm{OH}$ \\
$\mathrm{OH}-8$ & $11.95 / 12.60(s)$ & - & Chelated $\mathrm{OH}$ \\
$\mathrm{OH}-2$ & $14.18(s)$ & - & Chelated $\mathrm{OH}$ \\
$\mathrm{CO}-3$ ' & - & 203.7 & ketonic ' $\mathrm{C}$ ' \\
\hline
\end{tabular}

Key: m-multiplicity, dd-double-doublet, t-triplet, s-singlet, $\delta$-chemical shift in ppm.

Table $2{ }^{1} \mathrm{H},{ }^{13} \mathrm{CNMR}$ and $\mathrm{HMQC}$ and $\mathrm{HMBC}$ correlation for compound $\mathrm{GZ}-1\left(\mathrm{CDCl}_{3}\right)$.

\begin{tabular}{ccccc}
\hline \multirow{2}{*}{ C No } & ${ }^{1}$ HNMR $\boldsymbol{\delta}_{\mathbf{H}}(\boldsymbol{m})$ & ${ }^{13} \mathbf{C}$ NMR HMQC & HMBC & DEPT spectra \\
\hline 2 & $7.30(s)$ & 120.2 & $\mathrm{C}-3, \mathrm{C}-4, \mathrm{C}-1 \mathrm{a}, \mathrm{C}-4 \mathrm{a}$ & Description \\
5 & $7.58(d d)$ & 125.1 & $\mathrm{C}-5 \mathrm{a}, \mathrm{C}-6, \mathrm{C}-7, \mathrm{C}-8$ & $\mathrm{CH}$ \\
6 & $7.60(t)$ & 137.3 & $\mathrm{C}-5, \mathrm{C}-5 \mathrm{a}, \mathrm{C}-7, \mathrm{C}-8, \mathrm{C}-8 \mathrm{a}$ & $\mathrm{CH}$ \\
7 & $7.22(d d)$ & 115.6 & $\mathrm{C}-6, \mathrm{C}-5, \mathrm{C}-8, \mathrm{C}-8 \mathrm{a}, \mathrm{C}-5 \mathrm{a}$ & $\mathrm{CH}$ \\
5 & $6.15(s)$ & 90.0 & $\mathrm{C}-4$ ', C-6', C-3', C-1' & $\mathrm{CH}$ \\
$\mathrm{Me}-3$ & $2.16(s)$ & 21.6 & $\mathrm{C}-2, \mathrm{C}-3, \mathrm{C}-4$ & $\mathrm{CH}_{3}$ \\
3 '-Me & $2.66(s)$ & 33.3 & $\mathrm{C}-3$ ' & $\mathrm{CH}_{3}$ \\
4'-OMe $^{\prime}$ & $3.95(s)$ & 55.7 & & $\mathrm{CH}_{3}$ \\
\hline
\end{tabular}

The ${ }^{1} \mathrm{H}$ NMR spectrum of GZ-1 exhibited two methyl, one methoxy, five aromatic protons and three chelated hydroxyl signals. Three of the aromatic protons (ring $\mathbf{C}$ ) form an ABX spin system. Based on the broad band decoupled ${ }^{13} \mathrm{C}$ and DEPT spectra, 24 signals were evident and sixteen quaternary, five methine, one methoxy and two methyl carbons, were observed, confirming the naphthalene nature of the compound. The positions of the hydroxyl, methoxy, methyl and acetyl groups were established by HMBC and HSQC spectra (Figure 1). 


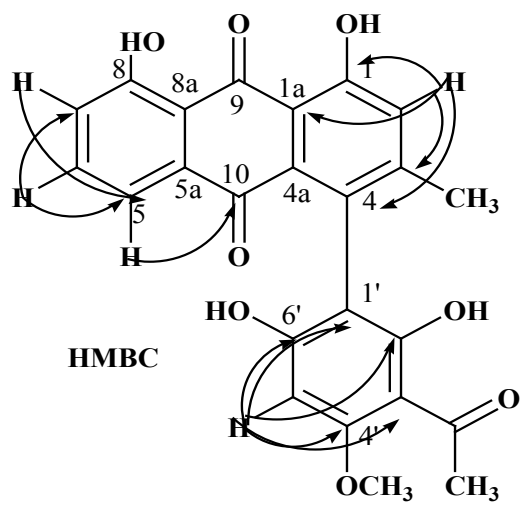

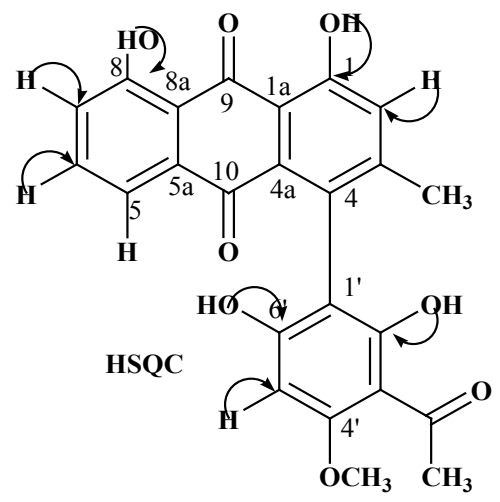

Figure 1 The HMBC and HSQC structure of GZ-1 compound (Knipholone).

\section{Evaluation of Antibacterial Activities}

The extracts of petroleum ether, chloroform, acetone and methanol and the isolated compound (GZ1) alone and along with $\mathrm{ZnCl}_{2}$ were tested in vitro against four bacterial strains (Tables 3 and 4).

The activities of the tested samples were reasonably assessed by the diameter of zone of growth inhibition in millimeters $(\mathrm{mm})$ and zones of inhibition more than $6 \mathrm{~mm}$ were taken into consideration. Among crude extracts, acetone has displayed superior activity against the four strains.

The acetone crude extracts zone of growth inhibition has displayed that $12.6 \pm 0.39,11.8 \pm 0.41$, $10.7 \pm 0.32$ and $9.7 \pm 0.28$ in $\mathrm{mm}$ against E.coli (ATCC25722), K. pnemonia (DSM 19613), S.aureus (ATCC 25925) and S. Typhimurium (ATCC 13311), respectively. The isolated compound (GZ-1) has demonstrated better zone of growth inhibition than the crude extracts except for K. pnemonia. Whereas, the combined crude extracts with $\mathrm{ZnCl}_{2}$, and isolated compound with $\mathrm{ZnCl}_{2}$ showed remarkable antibacterial activities (Table 4) than crude extract and isolated compound toward E.coli, S.aureus and $S$. Typhimurium bacterial strain which may be due to Complexation [13] which result in enhanced lipo solubility of the compounds so that easy penetration through the cell membranes of the bacteria thus easily attack the cell part. And the other way by which the antibacterial activity can be enhanced is because of synergetic effect [12], which means the extracts and metal ions act on different receptor of the bacterial cells thus do have higher inhibitory effect than crude extract, and isolated compound (GZ-1). Actually, isolated compound with $\mathrm{ZnCl}_{2}$ did not show zone of growth inhibition against K. pnemonia.

Table 3 Antibacterial activities of crude extracts and isolated compound of Kniphofia pumila.

\begin{tabular}{lcccc}
\hline \multirow{2}{*}{ Sample } & \multicolumn{4}{c}{ Diameter of zone of growth inhibition (mm) (Mean \pm S.D.) } \\
\cline { 2 - 5 } & \multicolumn{4}{c}{ Bacterial Strains } \\
\cline { 2 - 5 } & $\boldsymbol{E}$. coli & K. pnemonia & S. aureus & S. Typhimurium \\
\hline Petroleum Ether extract & NA & NA & $12 \pm 0.45$ & NA \\
Chloroform extract & $9.7 \pm 0.38$ & NA & $10.8 \pm 0.45$ & NA \\
Acetone extract & $12.6 \pm 0.39$ & $11.8 \pm 0.41$ & $10.7 \pm 0.32$ & $9.7 \pm 0.28$ \\
Methanol extract & NA & NA & $10.7 \pm 0.39$ & NA \\
Isolated compound (GZ-1) & $14 \pm 0.13$ & NI & $16 \pm 0.42$ & $12 \pm 0.13$ \\
Gentamycin & $16 \pm 0.19$ & $18 \pm 0.25$ & $13 \pm 0.17$ & $15 \pm 0.15$ \\
DMSO & NI & NI & NI & NI \\
\hline
\end{tabular}

Key: $\mathrm{NI}=$ No inhibition, $\mathrm{NA}=$ Not active, $\mathrm{SD}=$ standard deviation 
http://wjst.wu.ac.th

Table 4 Antibacterial activities of crude extracts and isolated compound of $K$. pumila along with $\mathrm{ZnCl}_{2}$.

\begin{tabular}{lcccc}
\hline \multirow{2}{*}{\multicolumn{1}{c}{ Sample }} & \multicolumn{4}{c}{ Diameter of zone of growth inhibition (mm) (Mean \pm S.D.) } \\
\cline { 2 - 5 } & \multicolumn{4}{c}{ Bacterial strains } \\
\cline { 2 - 5 } & E.coli & K. pnemonia & S. aureus & S. Typhimurium \\
\hline Petroleum Ether extract and $\mathrm{ZnCl}_{2}$ & $23 \pm 0.34$ & $20 \pm 0.42$ & $11 \pm 0.29$ & $10 \pm 0.44$ \\
Chloroform extract and $\mathrm{ZnCl}_{2}$ & $21 \pm 0.53$ & $20 \pm 0.33$ & $15 \pm 0.57$ & $11 \pm 0.41$ \\
Acetone extract and $\mathrm{ZnCl}_{2}$ & $12 \pm 0.23$ & $25 \pm 0.44$ & $11 \pm 0.31$ & $12 \pm 0.28$ \\
Methanol extract and $\mathrm{ZnCl}_{2}$ & $20 \pm 0.61$ & $18 \pm 0.72$ & $14 \pm 0.58$ & $18 \pm 0.59$ \\
Isolated compound (GZ-1) and $\mathrm{ZnCl}_{2}$ & $23 \pm 0.32$ & $\mathrm{NA}$ & $19 \pm 0.27$ & $24 \pm 0.59$ \\
Gentamycin & $18 \pm 0.19$ & $12 \pm 0.25$ & $17 \pm 0.11$ & $14 \pm 0.15$ \\
DMSO & $\mathrm{NI}$ & $\mathrm{NI}$ & $\mathrm{NI}$ & $\mathrm{NI}$ \\
\hline
\end{tabular}

Key: $\mathrm{NI}=$ No inhibition NA $=$ Not active

\section{Conclusions}

In the current study, one compound GZ-1 was chosen for characterization based on the biological activity and purity from the acetone extract of $K$. pumila roots, fractionated and purified by column chromatography packed with the silica gel (60 - 120 mesh size) with increasing gradient of ethyl acetate in n-hexane. Among, the pure compound displayed a significant bacterial activity was submitted to spectroscopic for characterization and was analyzed. Therefore, compound GZ-1 was identified as 3'acetyl-2',6'-dihydroxy-4-methoxyphenyl-1,8-dihydroxy-3-methylanthraquinone, trivial name knipholone. The result of antibacterial activities of the crude extracts and isolated compound alone were relatively small, even on some strains, no activity recorded. The antibacterial activity of isolated compound with $\mathrm{ZnCl} 2$ against $K$. pnemonia has no zone of inhibition. Meanwhile, antibacterial activities result against the rest of the three strains for combined crude extracts with $\mathrm{ZnCl}_{2}$, and isolated compound with $\mathrm{ZnCl}_{2}$ were good and very comparable, even in some cases greater than the antibacterial activities recorded for the standard drug (gentamycin), because Zn metal complexes are known to accelerate the drug action and efficacy of the organic therapeutic agent. Since the result has promising antibacterial activities, its in vivo, antifungal activities are recommended, and detail analysis shall follow.

\section{Acknowledgements}

The authors would like to acknowledge Jimma University, for providing laboratory facility and financial fund support from the College of Natural Science Mega Project fund.

\section{References}

[1] M Sathiya and K Muthuchelian. Phytochemical investigation and antibacterial screening of ethanolic leaf extract of Sapinduse marginatus vahl. Ethnobotanical Leaflets 2008, 12, 891-5.

[2] J Parekh and SV Chanda. In vitro antimicrobial activity and phytochemical analysis of some Indian medicinal plants. Turk. J. Biol. 2007, 31, 53-8.

[3] Y Chin, MJ Balunas, HB Chaiand and AD Kinghorn. Drug discovery from natural sources. AAPS J. 2006, 8, 239-53.

[4] W En-Erick, B Dudtshoorn and N Gericke. Medicinal Plants of South Africa. Briza Pretoria, South Africa, 1997, p. 304. 
http://wjst.wu.ac.th

[5] MN Desai and NS Chavan. Antibacterial activity and phytochemical screening of Cynometrairipa Kostel. J. Pharma. Bio. Sci. 2010, 1, 1-4.

[6] E Fikadu and M Melesse. Endemic plant species composition and their status in Boda Dry Evergreen Montane Forest, West Showa, Ethiopia. J. Biol. Conserv. 2014, 6, 563-9.

[7] D Kebele, A Alemayehu, G Binyam and M Yunis. A historical overview of traditional medicine practices and policy in Ethiopia. Ethiop. J. Health Dev. 2006, 20, 127-34

[8] Y Yeonjoong, Y Soon, Y Shin, S Lee, K Ho and H Young. A compound isolated from Rumexjaponicus induces apoptosis in HeLa cells. J. Biol. Chem. 2010, 53, 657-60.

[9] K Urga, A Asefa and M Guta. Traditional medicine in Ethiopia. In: Proceedings of the National Workshop Held in Addis Ababa, Ethiopia, 2004, p. 145-67.

[10] Y Daia, L Harinantenainaa, J Bowmanb, OD Fonsecab, IP Brodiea, M Goetzc, M Casserab and G Kingston. Isolation of antiplasmodial anthraquinones from Kniphofia ensifolia, and synthesis and structure-activity relationships of related compounds. Bioorg. Med. Chem. 2014, 22 269-76.

[11] MK Prashanth, HD Revanasiddappa, KML Rai, KA Raveesha and B Jayalakshmi. Antibacterial, anthelmintic and antioxidant activity of Argyreia elliptica extracts: Activity enhancement by the addition of metal salts. Int. J. App. Res. Nat. Prod. 2013, 6, 1-10.

[12] SJ Prabhjot, K Gagandeep and K Loveleen. Synergistic effect of Curcuma longa and Glycyrrhiza glabra extracts with copper ions on food spoilage bacteria. Int. J. Pharm. Sci. 2015; 7, 371-5.

[13] SWJ Gould, MD Fielder, AF Kelly and DP Naughton. Anti-microbial activities of pomegranate rind extracts: enhancement by cupric sulphate against clinical isolates of $S$. aureus, MRSA and PVL positive CA-MSSA. BMC Compl. Altern. Med. 2009, 9, 1-6.

[14] M Rahman, MG Mostafa and MM Karim. The bactericidal activity of medicinal plants, Terminala chebula is enhanced upon addition of manganese salts. Int. J. Med. Plants. 2012, 2, 214-2. 